\title{
ANALISIS MISKONSEPSI SISWA PADA MATERI FISIKA DI SMA NEGERI 8 HALMAHERA TIMUR MENGGUNAKAN CERTAINTY OF RESPONSE INDEX (CRI)
}

\author{
Feliks Robo, Rolles Nixon Palilingan, Aswin Hermanus Mondolang \\ Fakultas Matematika dan Ilmu Pengetahuan Alam, Universitas Negeri Manado \\ email: feliksrobo@gmail.com
}

\begin{abstract}
ABSTRAK
Pada proses pembelajaran fisika salah satu hal yang diperhatiakan adalah mengembangkan perubahan konsep siswa memperluas konsep dari konsep yang belum lengkap menjadi lengkap dan sempurna. Konsep tersebut seringkali menyimpamg dari konsep yang benar. Penyimpangan konsep inilah yang disebut dengan miskonsepsi. Miskonsepsi adalah konsep awal yang tidak sesuai dengan konsep ilmiah yang disepakati para ahli. Penelitian ini bertujuan untuk mengetahui Tingkat Miskonsepsi Siswa Pada Materi Fisika Di SMA Negeri 8 Halmahera Timur Menggunakan Certainty Of Response Index. Subjek yang digunakan pada penelitian ini adalah siswa kelas XII MIA di SMA Negeri 8 Halmahera Timur sebanyak 30 orang. Pengambilan data dalam penelitian ini berupa tes diagnosis multiple choice (pilihan ganda beralasan) 50 nomor disertai Certainty of Response Index (CRI) siswa pada materi Usaha dan Energi 15 butir soal, Suhu dan Kalor 17 butir soal serta Listrik Statis 18 butir soal. Data dianalisis secara kualitatif, dari hasil analisis data diperoleh kesimpulan : Tingkat miskonsepsi pada materi suhu dan kalor sebanyak 47 $\%$ yang merupakan miskonsepsi tertinggi dari ketiga materi, ini membuktikan bahwa sebagian besar siswa tidak memahami tentang materi suhu dan kalor dibandingkkan dengan materi Usaha dan Energi dengan tingkat miskonsepsi 13\%, serta listrik statis yang mengalami miskonsepsi sebanyak $20 \%$. Secara keseluruhan tingkat miskonsepsi siswa masih tergolong rendah yaitu mencapai $35 \%$.
\end{abstract}

Kata kunci : Miskonsepsi, Certainty Of Response Index (CRI)

\begin{abstract}
In the physics learning process, one of the things to look out for is developing a change in the student's concept that extends the concept from incomplete concepts to complete and perfect. These concepts often deviate from the correct concept. Misconception are initial concepts that are inconsistent with the scientific concepts agreed by experts. This departure from the concept is known as a misunderstanding. This study aims to determine the extent of student misunderstandings in physics material at SMA Negeri 8 East Halmahera using the Certainty Of Response Index. The subjects used in this study were 30 students from Class XII MIA at SMA Negeri 8 East Halmahera. Retrieving data in this study in the form of a multiple choice diagnostic test (reasoned multiple choice test) 50 numbers, accompanied by the CRI (Certainty of Response Index) of the students on Effort and energy 15 items, Temperature and Heat 17 items and 18 static electricity. The data were analyzed qualitatively. From the results of the data analysis, the following conclusion emerged: The degree of misconception of material temperature and heat was 47\%. This was the ultimate misconception of the three materials. This proves that most of the students do not understand the material temperature and heat compared to the material from Effort and energy with a misunderstanding rate was $13 \%$, and the static electricity where a misunderstanding occurred was $20 \%$. Overall, the misunderstanding among students is still low at $35 \%$.
\end{abstract}

Keywords : Misconception, Certainty Of Response Index (CRI) 


\section{PENDAHULUAN}

Pada proses pembelajaran fisika salah satu hal yang diperhatiakan adalah mengembangkan perubahan konsep siswa memperluas konsep dari konsep yang belum lengkap menjadi lengkap dan sempurna. Pada dasarnya sebelum mengikuti proses pembelajaran fisika secara formal disekolah, siswa sudah memiliki konsepsi awal tentang fisika. Konsep tersebut seringkali menyimpamg dari konsep yang benar (Baser 2006). Penyimpangan konsep inilah yang disebut dengan miskonsepsi.

Menurut (Ahlif 2014), miskonsepsi merupakan penafsiran konsep oleh siswa tidak sesuai dengan konsep yang dikemukakan oleh ilmuwan. Dan menurut (Andriani, 2015) Miskonsepsi adalah konsep awal yang tidak sesuai dengan konsep ilmiah yang disepakati para ahli. Apa bila dalam pembelajaran tanpa memperhatikan miskonsepsi yang sudah ada dalam kognisi siswa sebelumnya ketika proses pembelajaran berlangsung maka guru kurang berhasil menanamkan konsep yang benar sehingga dapat megakibatkan kekurang mampuan mereka dalam memecahkan soalsoal dalam fisika. Secara umum miskonsepsi dapat disebabkan oleh oleh siswa sendiri, guru yang mengajar, konteks pembelajaran, cara mengajar dan buku teks.

Berdasarkan hasil observasi awal terhadap 20 siswa kelas XII MIA SMA N 8 Halmahera Timur yang telah diberikan berupa angket 15 diantaranya sulit memahami konsep fisika terkait Usaha dan Energi, Suhu dan Kalor serta Listrik Statis. Hal ini dikarenakan kurangnya media pembelajaran yang menarik karena keterbatasan tenaga provesi bidang fisika. Selain itu kurangnya buku penunjang dan lab fisika juga salah satu faktor yang menjadi keterbatasan pengetahuan pada anak-anak kerana minimnya eksplorasi atau praktikum secara langsung sehingga penulis ingin meneliti tingkat miskonsepsi siswa pada materi fisika dengan menggunakan certainty of response indix (cri) agar tingkat miskonsepsi dapat diketahui dan dapat direduksi.

Untuk selanjutnya mengidentifikasi miskonsepsi digunakan tes diagnosis multiple choice dengan reasoning terbuka disertai Certainty of Response Index (CRI) tanpa memberikan perlakuan atau treatmen kepada siswa sehingga data yang dihasilkan adalah data alamiah siswa. CRI (Certainty of Response Index) merupakan ukuran tingkat keyakinan/kepastian responden dalam menjawab setiap pertanyaan (soal) yang diberikan ( Tayubi 2005: 5). Siswa yang menjadi subjek menjawab option a, b, c dan d kemudian menuliskan alasan atas jawabannya serta memilih CRI (Certainty of Response Index) pada kolom yang sudah disediakan untuk mengetahui tingkat keyakinan siswa dalam menjawab soal.

Berdasarkan pernyataan dan permasalahan diatas, peneliti tertarik untuk mengetahui miskonsepsi yang terjadi pada pelajaran fisika dengan judul penelitian Analisis Miskonsepsi Siswa Pada Materi Fisika Di SMA Negeri 8 Halmahera Timur Menggunakan Certainty Of Response Index (CRI).

\section{METODE PENELITIAN}

Jenis penelitian ini adalah penelitian deskriptif dengan menggunakan metode kualitatif. Penelitian ini telah dilaksankan pada tanggal 22 Maret 2021 di SMA Negeri 8 Halmahera Timur subjek yang digunakan adalah siswa kelas XII MIA SMA Negeri 8 Halmahera Timur tahun pelajaran 2020/2021 sebanyak 30 orang siswa.

\section{Desain}

Pada penelitian ini, digunakan tes diagnosis multiple choice (pilihan ganda beralasan) disertai Certainty of Response Index (CRI) untuk mengetahui miskonsepsi siswa pada materi Usaha dan Energi, Suhu dan Kalor sert Listrik Statis. Soal yang digunakan adalah pilihan ganda beralasan 50 soal sehingga siswa dapat mengungkapkan pendapatnya ketika mejawab soal. Kriteria penilaian miskonsepsi menggunakan teknik CRI termodifikasi yang ditunjukan pada tabel 1 dan 2.

Dari hasil perhitungan Tingkat Miskonsepsi Setiap Siswa, dibagi atas lima kelompok tingkat miskonsepsi seperti pada tabel 3.

Tabel 1. CRI dan kriterianya (Derajat Keyakinan Siswa Dalam Menjawab Soal)

\begin{tabular}{ll}
\hline CRI & Kriteria \\
\hline 0 & $\begin{array}{c}\text { (totally gues answer) jawaban } \\
\text { menebak }\end{array}$ \\
\hline 1 & $\begin{array}{c}\text { (almost a guess) (hampir } \\
\text { menebak/sangat tidak yakin) }\end{array}$ \\
\hline 2 & (not sure) (tidak yakin) \\
\hline 3 & (sure)(yakin) \\
\hline 4 & (almost certain) (hampir pasti) \\
\hline 5 & (certain) (jawaban pasti/ \\
& amat sangat yakin) \\
\hline
\end{tabular}


Tabel 2. Kriteria Penilaian dengan teknik Modifikasi CRI

\begin{tabular}{llll}
\hline Jawaban Alasan & $\begin{array}{l}\text { Nilai } \\
\text { CRI }\end{array}$ & Deskripsi \\
\hline Benar & Benar & $>2,5$ & $\begin{array}{l}\text { Paham konsep } \\
\text { dengan baik }\end{array}$ \\
\hline Benar & Benar & $<2,5$ & $\begin{array}{l}\text { Paham konsep } \\
\text { tapi tidak yakin }\end{array}$ \\
\hline Benar & Salah & $>2,5$ & Miskonsepsi \\
\hline Benar & Salah & $<2,5$ & $\begin{array}{l}\text { Tidak paham } \\
\text { konsep }\end{array}$ \\
\hline Salah & Benar & $>2,5$ & Miskonsepsi \\
\hline Salah & Benar & $<2,5$ & $\begin{array}{l}\text { Tidak paham } \\
\text { Konsep }\end{array}$ \\
\hline Salah & Salah & $>2,5$ & Miskonsepsi \\
\hline Salah & Salah & $<2,5$ & $\begin{array}{l}\text { Tidak paham } \\
\text { konsep }\end{array}$ \\
\hline & & & \\
\hline & & &
\end{tabular}

Tabel 3. Pengelompokan Tingkat Miskonsepsi Setiap Siswa

$$
\begin{aligned}
& \text { Tingkat Miskonsepsi Persentase } \\
& \text { Miskonsepsi }
\end{aligned}
$$

Siswa

\begin{tabular}{ll}
\hline Sangat Rendah & $0 \%-19,99 \%$ \\
\hline Rendah & $20 \%-39,99 \%$ \\
\hline Sedang & $40 \%-59,99 \%$ \\
\hline Tinggi & $60 \%-79,99 \%$ \\
\hline Sangat Tinggi & $80 \%-100 \%$
\end{tabular}

\section{HASIL DAN PEMBAHASAN Hasil Penelitian}

Persentase data siswa secara keseluruhan dapat dilihat pada tabel 4 data peserta didik berdasarkan kriteria Paham Konsep (PK), Paham Konsep Tetapi Tidak Yakin (PKTTY), Tidak Paham Konsep (TPK), dan Miskonsepsi (M) pada tiap butir soal.

Tabel 4. Data peserta didik pada tiap butir soal

\begin{tabular}{lccccc}
\hline $\begin{array}{l}\text { No. } \\
\text { Soal }\end{array}$ & PK & PKTTY & TPK & M & Jumlah \\
\hline 1 & $23 \%$ & $3 \%$ & $10 \%$ & $63 \%$ & $100 \%$ \\
\hline 2 & $30 \%$ & $20 \%$ & $20 \%$ & $30 \%$ & $100 \%$ \\
\hline 3 & $13 \%$ & $13 \%$ & $47 \%$ & $27 \%$ & $100 \%$ \\
\hline 4 & $10 \%$ & $17 \%$ & $23 \%$ & $50 \%$ & $100 \%$ \\
\hline 5 & $20 \%$ & $23 \%$ & $37 \%$ & $20 \%$ & $100 \%$ \\
\hline 6 & $23 \%$ & $0 \%$ & $30 \%$ & $47 \%$ & $100 \%$ \\
\hline 7 & $17 \%$ & $10 \%$ & $27 \%$ & $47 \%$ & $100 \%$ \\
\hline 8 & $7 \%$ & $13 \%$ & $50 \%$ & $30 \%$ & $100 \%$ \\
\hline 9 & $63 \%$ & $7 \%$ & $3 \%$ & $27 \%$ & $100 \%$ \\
\hline & & & & & \\
\end{tabular}

\begin{tabular}{cccccc}
\hline 10 & $7 \%$ & $17 \%$ & $33 \%$ & $43 \%$ & $100 \%$ \\
\hline 11 & $43 \%$ & $13 \%$ & $27 \%$ & $17 \%$ & $100 \%$ \\
\hline 12 & $10 \%$ & $20 \%$ & $50 \%$ & $20 \%$ & $100 \%$ \\
\hline 13 & $13 \%$ & $10 \%$ & $33 \%$ & $43 \%$ & $100 \%$ \\
\hline 14 & $13 \%$ & $0 \%$ & $40 \%$ & $47 \%$ & $100 \%$ \\
\hline 15 & $13 \%$ & $23 \%$ & $47 \%$ & $17 \%$ & $100 \%$ \\
\hline 16 & $27 \%$ & $7 \%$ & $20 \%$ & $47 \%$ & $100 \%$ \\
\hline 17 & $10 \%$ & $10 \%$ & $30 \%$ & $50 \%$ & $100 \%$ \\
\hline 18 & $17 \%$ & $23 \%$ & $37 \%$ & $23 \%$ & $100 \%$ \\
\hline 19 & $7 \%$ & $10 \%$ & $63 \%$ & $20 \%$ & $100 \%$ \\
\hline 20 & $20 \%$ & $0 \%$ & 27 & $53 \%$ & $100 \%$ \\
\hline 21 & $40 \%$ & $7 \%$ & $23 \%$ & $30 \%$ & $100 \%$ \\
\hline 22 & $50 \%$ & $7 \%$ & $17 \%$ & $27 \%$ & $100 \%$ \\
\hline 23 & $10 \%$ & $13 \%$ & $30 \%$ & $47 \%$ & $100 \%$ \\
\hline 24 & $3 \%$ & $13 \%$ & $50 \%$ & $33 \%$ & $100 \%$ \\
\hline 25 & $10 \%$ & $7 \%$ & $20 \%$ & $63 \%$ & $100 \%$ \\
\hline 26 & $7 \%$ & $17 \%$ & $47 \%$ & $30 \%$ & $100 \%$ \\
\hline 27 & $3 \%$ & $13 \%$ & $50 \%$ & $33 \%$ & $100 \%$ \\
\hline 28 & $3 \%$ & $7 \%$ & $23 \%$ & $63 \%$ & $100 \%$ \\
\hline 29 & $0 \%$ & $10 \%$ & $53 \%$ & $37 \%$ & $100 \%$ \\
\hline 30 & $17 \%$ & $13 \%$ & $40 \%$ & $30 \%$ & $100 \%$ \\
\hline 31 & $20 \%$ & $20 \%$ & $23 \%$ & $37 \%$ & $100 \%$ \\
\hline 32 & $17 \%$ & $7 \%$ & $30 \%$ & $47 \%$ & $100 \%$ \\
\hline 33 & $7 \%$ & $23 \%$ & $40 \%$ & $30 \%$ & $100 \%$ \\
\hline 34 & $3 \%$ & $10 \%$ & $50 \%$ & $37 \%$ & $100 \%$ \\
\hline 35 & $33 \%$ & $37 \%$ & $7 \%$ & $23 \%$ & $100 \%$ \\
\hline 36 & $20 \%$ & $10 \%$ & $30 \%$ & $40 \%$ & $100 \%$ \\
\hline 37 & $17 \%$ & $27 \%$ & $30 \%$ & $27 \%$ & $100 \%$ \\
\hline 38 & $7 \%$ & $30 \%$ & $27 \%$ & $37 \%$ & $100 \%$ \\
\hline 39 & $10 \%$ & $17 \%$ & $50 \%$ & $23 \%$ & $100 \%$ \\
\hline 40 & $23 \%$ & $13 \%$ & $30 \%$ & $33 \%$ & $100 \%$ \\
\hline 41 & $7 \%$ & $10 \%$ & $53 \%$ & $30 \%$ & $100 \%$ \\
\hline 42 & $13 \%$ & $7 \%$ & $50 \%$ & $30 \%$ & $100 \%$ \\
\hline 43 & $30 \%$ & $23 \%$ & $10 \%$ & $37 \%$ & $100 \%$ \\
\hline 44 & $10 \%$ & $13 \%$ & $37 \%$ & $40 \%$ & $100 \%$ \\
\hline 45 & $20 \%$ & $7 \%$ & $33 \%$ & $40 \%$ & $100 \%$ \\
\hline 46 & $13 \%$ & $17 \%$ & $37 \%$ & $33 \%$ & $100 \%$ \\
\hline 47 & $27 \%$ & $13 \%$ & $37 \%$ & $23 \%$ & $100 \%$ \\
\hline 48 & $20 \%$ & $3 \%$ & $40 \%$ & $37 \%$ & $100 \%$ \\
\hline 49 & $13 \%$ & $10 \%$ & $47 \%$ & $30 \%$ & $100 \%$ \\
\hline 50 & $20 \%$ & $7 \%$ & $53 \%$ & $20 \%$ & $100 \%$ \\
\hline $\bar{x}$ & $\mathbf{1 7 . 2 \%}$ & $\mathbf{1 3 \%}$ & $\mathbf{3 4 . 4 \%}$ & $\mathbf{3 5 . 4 \%}$ & $\mathbf{1 0 0 \%}$ \\
\hline & & & & & \\
\hline 13
\end{tabular}

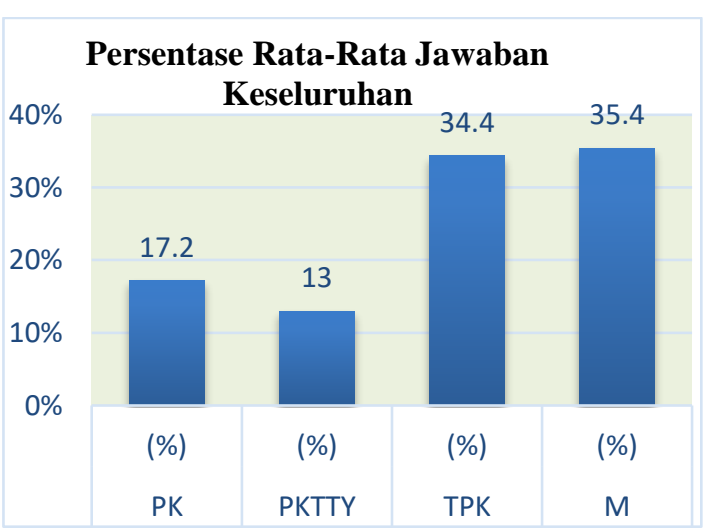

Gambar 1 Persentase rata-rata jawaban peserta didik secara keseluruhan 
Hasil penelitian berdasarkan materi dapat di sajikan pada tabel 5, tabel 6 dan tabel 7 . Tabel 5. Persentase PK, PKTTY, TPK, dan M pada materi Usaha dan Energi

\section{No. PK PKTTY TPK M Jumlah Soal}

\begin{tabular}{lccccc}
\hline 1 & $23 \%$ & $3 \%$ & $10 \%$ & $63 \%$ & $100 \%$ \\
\hline 2 & $30 \%$ & $20 \%$ & $20 \%$ & $30 \%$ & $100 \%$ \\
\hline 3 & $13 \%$ & $13 \%$ & $47 \%$ & $27 \%$ & $100 \%$ \\
\hline 4 & $10 \%$ & $17 \%$ & $23 \%$ & $50 \%$ & $100 \%$ \\
\hline 5 & $20 \%$ & $23 \%$ & $37 \%$ & $20 \%$ & $100 \%$ \\
\hline 6 & $23 \%$ & $0 \%$ & $30 \%$ & $47 \%$ & $100 \%$ \\
\hline 7 & $17 \%$ & $10 \%$ & $27 \%$ & $47 \%$ & $100 \%$ \\
\hline 8 & $7 \%$ & $13 \%$ & $50 \%$ & $30 \%$ & $100 \%$ \\
\hline 9 & $63 \%$ & $7 \%$ & $3 \%$ & $27 \%$ & $100 \%$ \\
\hline 10 & $7 \%$ & $17 \%$ & $33 \%$ & $43 \%$ & $100 \%$ \\
\hline 11 & $43 \%$ & $13 \%$ & $27 \%$ & $17 \%$ & $100 \%$ \\
\hline 12 & $10 \%$ & $20 \%$ & $50 \%$ & $20 \%$ & $100 \%$ \\
\hline 13 & $13 \%$ & $10 \%$ & $33 \%$ & $43 \%$ & $100 \%$ \\
\hline 14 & $13 \%$ & $0 \%$ & $40 \%$ & $47 \%$ & $100 \%$ \\
\hline 15 & $13 \%$ & $23 \%$ & $47 \%$ & $17 \%$ & $100 \%$ \\
\hline$\overline{\boldsymbol{x}}$ & $\mathbf{2 0 \%}$ & $\mathbf{1 3 \%}$ & $\mathbf{3 2 \%}$ & $\mathbf{3 5 \%}$ & $\mathbf{1 0 0 \%}$ \\
\hline
\end{tabular}

Tabel 6. Persentase PK, PKTTY, TPK, dan M pada materi Suhu dan Kalor

\begin{tabular}{lccccc}
\hline $\begin{array}{l}\text { No. } \\
\text { Soal }\end{array}$ & PK & PKTTY & TPK & M & Jumlah \\
\hline 16 & $27 \%$ & $7 \%$ & $20 \%$ & $47 \%$ & $100 \%$ \\
\hline 17 & $10 \%$ & $10 \%$ & $30 \%$ & $50 \%$ & $100 \%$ \\
\hline 18 & $17 \%$ & $23 \%$ & $37 \%$ & $23 \%$ & $100 \%$ \\
\hline 19 & $7 \%$ & $10 \%$ & $63 \%$ & $20 \%$ & $100 \%$ \\
\hline 20 & $20 \%$ & $0 \%$ & 27 & $53 \%$ & $100 \%$ \\
\hline 21 & $40 \%$ & $7 \%$ & $23 \%$ & $30 \%$ & $100 \%$ \\
\hline 22 & $50 \%$ & $7 \%$ & $17 \%$ & $27 \%$ & $100 \%$ \\
\hline 23 & $10 \%$ & $13 \%$ & $30 \%$ & $47 \%$ & $100 \%$ \\
\hline 24 & $3 \%$ & $13 \%$ & $50 \%$ & $33 \%$ & $100 \%$ \\
\hline 25 & $10 \%$ & $7 \%$ & $20 \%$ & $63 \%$ & $100 \%$ \\
\hline 26 & $7 \%$ & $17 \%$ & $47 \%$ & $30 \%$ & $100 \%$ \\
\hline 27 & $3 \%$ & $13 \%$ & $50 \%$ & $33 \%$ & $100 \%$ \\
\hline 28 & $3 \%$ & $7 \%$ & $23 \%$ & $63 \%$ & $100 \%$ \\
\hline 29 & $0 \%$ & $10 \%$ & $53 \%$ & $37 \%$ & $100 \%$ \\
\hline 30 & $17 \%$ & $13 \%$ & $40 \%$ & $30 \%$ & $100 \%$ \\
\hline 31 & $20 \%$ & $20 \%$ & $23 \%$ & $37 \%$ & $100 \%$ \\
\hline 32 & $17 \%$ & $7 \%$ & $30 \%$ & $47 \%$ & $100 \%$ \\
\hline $\bar{x}$ & $\mathbf{1 5 \%}$ & $\mathbf{1 1 \%}$ & $\mathbf{3 4 \%}$ & $\mathbf{4 0 \%}$ & $\mathbf{1 0 0 \%}$ \\
\hline
\end{tabular}

Tabel 7. Persentase PK, PKTTY, TPK, dan M pada materi Listrik Statis

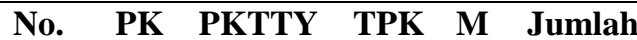 Soal}

\begin{tabular}{cccccc}
\hline 33 & $7 \%$ & $23 \%$ & $40 \%$ & $30 \%$ & $100 \%$ \\
\hline 34 & $3 \%$ & $10 \%$ & $50 \%$ & $37 \%$ & $100 \%$ \\
\hline 35 & $33 \%$ & $37 \%$ & $7 \%$ & $23 \%$ & $100 \%$ \\
\hline 36 & $20 \%$ & $10 \%$ & $30 \%$ & $40 \%$ & $100 \%$ \\
\hline
\end{tabular}

\begin{tabular}{llllll}
\hline 37 & $17 \%$ & $27 \%$ & $30 \%$ & $27 \%$ & $100 \%$ \\
\hline 38 & $7 \%$ & $30 \%$ & $27 \%$ & $37 \%$ & $100 \%$ \\
\hline 39 & $10 \%$ & $17 \%$ & $50 \%$ & $23 \%$ & $100 \%$ \\
\hline 40 & $23 \%$ & $13 \%$ & $30 \%$ & $33 \%$ & $100 \%$ \\
\hline 41 & $7 \%$ & $10 \%$ & $53 \%$ & $30 \%$ & $100 \%$ \\
\hline 42 & $13 \%$ & $7 \%$ & $50 \%$ & $30 \%$ & $100 \%$ \\
\hline 43 & $30 \%$ & $23 \%$ & $10 \%$ & $37 \%$ & $100 \%$ \\
\hline 44 & $10 \%$ & $13 \%$ & $37 \%$ & $40 \%$ & $100 \%$ \\
\hline 45 & $20 \%$ & $7 \%$ & $33 \%$ & $40 \%$ & $100 \%$ \\
\hline 46 & $13 \%$ & $17 \%$ & $37 \%$ & $33 \%$ & $100 \%$ \\
\hline 47 & $27 \%$ & $13 \%$ & $37 \%$ & $23 \%$ & $100 \%$ \\
\hline 48 & $20 \%$ & $3 \%$ & $40 \%$ & $37 \%$ & $100 \%$ \\
\hline 49 & $13 \%$ & $10 \%$ & $47 \%$ & $30 \%$ & $100 \%$ \\
\hline 50 & $20 \%$ & $7 \%$ & $53 \%$ & $20 \%$ & $100 \%$ \\
\hline$\overline{\boldsymbol{x}}$ & $\mathbf{1 6 \%}$ & $\mathbf{1 5 \%}$ & $\mathbf{3 7 \%}$ & $\mathbf{3 2 \%}$ & $\mathbf{1 0 0 \%}$ \\
\hline
\end{tabular}

\section{Pembahasan}

Gambar 1 menunjukan secara keseluruhan diperoleh rata-rata persentase aspek paham konsep $17,2 \%$, paham konsep tapi tidak yakin $13 \%$, tidak paham konsep $34,4 \%$, miskonsepsi $35,4 \%$. Hasil ini menunjukan bahwa kategori miskonsepsi siswa paling tinggi dibandingkan dengan siswa yang paham konsep. Berdasrakan tabel 4.1 miskonsepsi dibagi menjadi tiga kelompok besar yaitu miskonsepsi tinggi, sedang dan rendah.

Kriteria tinggi dihasilkan sebanyak $67 \%$ pada butir soal nomor 28 yang dimana soal tersebut berindikator menentukan apa yang terjadi pada zat yang mempunyai kalor jenis tinggi.

Kriteria sedang sebanyak $53 \%$ pada butir soal nomor 20 yang dimana soal tersebut berindikator menyebutkan macam-macam sakla termometer.

Kriteria rendah $17 \%$ pada butir soal nomor 11 dan 15 dengan indikator soal menentukan besar energi potensial gravitasi dan menghitum perubahan energi potensial.

Pada materi usaha dan energi dari Tabel 4.5 diperoleh aspek paham konsep $20 \%$, paham konsep tapi tidak yakin $13 \%$, tidak paham konsep 32\%, miskonsepsi 35\%. Hasil ini menunjukan bahwa kategori miskonsepsi siswa paling tinggi dibandingkan dengan kategori lainnya. Miskonsepsi siswa pada kriteria tertinggi $63 \%$ pada nomor soal 1 dengan indikator menyebutkan pengertian usaha. Kriteria sedang 50\% dengan indikator soal mendefenisikan pengertian energi pada butir soal nomor 4. Kriteria rendah pada butir soal nomor 11 dan 15 dengan indikator soal menentukan besar energi potensial gravitasi dan menghitum perubahan energi potensial sebanya 
sebanyak $17 \%$.

Berdasarkan tabel persentase pada materi Suhu dan Kalor pada butir soal nomor 16 sampai 32 diperoleh rata-rata persentase $\mathrm{PK}$ $15 \%$, PKTTY $11 \%$, TPK $34 \%$, dan M 40\%. Miskonsepsi siswa pada kriteria tertinggi sebesar $67 \%$ pada butir soal no. 28 yang berindikator menganalisis perubahan zat yang diberikan kalor. $50 \%$ yang tergolong kriteria sedang pada butir soal nomor 17 dengan indakator memahami tentang pemuaian. Dan butir soal nomor 19 adalah miskonsepsi kriteria rendah $20 \%$ pada indikator menentukan skalah thermometer.

Dilihat dari tabel persentase pada materi Listrik Statis pada butir soal nomor 33 sampai 50 diperoleh rata-rata persentase PK $16 \%$, PKTTY 15\%, TPK 37\%, dan M 32\% khusunya pada materi Listrik Statis tidak memiliki miskonsepsi pada kriteria tinggi ini dilihat berdasarakan Tabel 3.4 tentang Pengelompokan Tingkat Miskonsepsi Setiap Siswa pada kriteria tinggi yaitu 60\%-79,99\%. Miskonsepsi siswa pada kriteria sedang sebesar $40 \%$ yang mencakup butir soal 36,44 , dan 45 dengan indakator menyebutkan sifat muatan listrik, menyebutkan faktor-faktor yang mempengaruhi kapasitas kapasitor serta memahami contoh listrik statis dalam kehidupan sehari-hari. Kriteria rendah 20\% yaitu menentukan besar kuat medan listrik dan potensial listrik pada butir soal 50.

Penelitian menganalisis miskonsepsi siswa kelas XII MIA SMA N 8 Halmahera Timur yang bertujuan untuk mengetahui tingkat miskonsepsi siswa didapati pada materi Usaha dan Energi 35\%, Suhu dan Kalor 40\%, serta Listrik Statis 32\% maka miskonsepsi terbesar terdapat pada materi suhu dan kalor yaitu sebesar $40 \%$ pada butir soal nomor 28 dengan persentase miskonsepsi $67 \%$ dan miskonsepsi terendah terdapat pada materi listrik statis yaitu sebesar 32\% pada butir soal nomor 11 dan 15 . Sedangkan Paham konsep rata-rata kategori tinggi $20 \%$ pada materi Usaha dan energi pada butir soal nomor 9 sebesar $63 \%$ dan paham konsep kategori rendah sebesar $15 \%$ materi Suhu dan Kalor pada butir soal nomor 29 yaitu $0 \%$. Data yang diperoleh dalam penelitian ini dari hasil tes pilihan ganda beralasan dengan dilengkapi CRI sebanyak 50 soal yang terdiri dari 15 butir soal Usaha dan Energi, 17 butir soal Suhu dan Kalor dan 18 butir soal Listrik Statis. Deskripsi hasil penelitian menunjukan bahwa siswa kelas XII MIA di SMA N 8 Halmahera Timur masih mengalami miskonsepsi atau salah konsep.

Dari hasil analisi data, ditemukan beberapa penyebab terjadi miskonsepsi siswa XII MIA antara lain siswa menghubungkan satu besaran dengan besaran lainya, siswa belum bisa membedakan dua besaran dan membuat pengertian yang salah, siswa belum memahami besaran - besaran yang bekerja pada suatu benda, siswa memberikan intuisi yang salah dikarenakan siswa jarang mengamati atau bereksperimen tentang peristiwa fisika secara langsung, dan yang terakhir siswa melakukan pengamatan yang kurang lengkap, sehingga mengambil kesimpulan yang salah.

\section{KESIMPULAN}

Berdasarkan hasil analisis dan pembahasan dari penelitian yang telah dilakukan dapat diambil kesimpulan bahwa siswa kelas XII MIA di SMA N 8 Halmahera Timur masih mengalami miskonsepsi atau salah konsep pada hampir semua indikator atau pada soal.

Tingkat miskonsepsi pada materi suhu dan kalor sebanyak $47 \%$ yang merupakan miskonsepsi tertinggi dari ketiga materi, ini membuktikan bahwa sebagian besar siswa tidak memahami tentang materi suhu dan kalor dibandingkan dengan materi Usaha dan Energi dengan tingkat miskonsepsi $13 \%$, serta listrik statis yang mengalami miskonsepsi sebanyak $20 \%$. Secara keseluruhan tingkat miskonsepsi siswa masih tergolong rendah yaitu mencapai $35 \%$.

\section{REFERENSI}

Annisa Dini Pratiwi, D. M. (2018). Analisis Miskonsepsi Pada Konsep Hukum-Hukum Newton Tentang Gerak.

Auliyak, P. (2020). Identifikasi Miskonsepsi Siswa Pada Materi Listrik Statis Dengan Menggunakan Test Diagnostic Four Tier.

Clement, J. B. (1989). Finding Anchoring Conception For Grounding Instruction on Students Intuitions.

Estavina Br Sitepu, M. Y. (2019). Miskonsepsi Siswa Pada Materi Hukum Newton di Kelas X IPA SMA Negeri 1 Berastgi.

Eviyani, T. A. (2017). Analisisi Miskonsepsi Fisika Pokok Bahasan Hukum Newton 
Tentang Gerak Dengan Teknik Certainty Of Response Index (CRI) Pada Siswa Kelas X Di SMA Xaverius Lubuklinggu Thun Pelajaran 2016/2017.

Fitria. (2019). Identiikasi Miskonsepsi Peserta Didik Menggunakan Four-Tier Diagnostic Test Disertai Certainty Of Response Index (CRI) Pada Materi Usaha Dan Energi.

Gumilar, S. (2016). Analisis Miskonsepsi Konsep Gaya Menggunakan Certainty Of Respon Index (CRI).

Indriyni, R. (2019). Implementasi Peta Konsep Untuk Mereduksi Miskonspsi Peserta Didik Pada Pembelajaran Fisika Materi Hukum Newton.

Jawan, A. P. (2017). Pemahaman Dan Miskonsepsi Tentang Konsep Gerak Dan Gaya Pada Siswa Kelas Xi Ipa Smak Frateran Maumere.

Juwita Febrianti, H. A. (2019). Analisis Miskonsepsi Suhu Dan Kalor Pada Siswa SMA Negeri 3 Tanjung Raya(JIPF).

Kirbulut, Z. D. (2014). Using Three- Tier Diagnostic Test to Assess Students' Misconceptions of States of Matter.

Labur, M. D. (2008). Miskonsepsi Terhadap Konsep Gerak Dan Gaya Dalam HukumHukum Newton Pada Siswa Kelas 1 SMA Di Kecamatan Langke Rembong, Kabupaten Manggarai Propinsi Nusa Tenggara Timur.

Lalu A. Didik, F. A. (2019). Analisis Tingkat Pemahaman Dan Miskonsepsi Pada Materi Listrik Statis Mahasiswa Tadris Fisika Menggunakan Metode 3-Tier Multiple Chois Diagnostic.

Muna, I. A. (2015). Identifikasi Miskonsepsi Mahasiswa Pgmi Pada Konsep Hukum Newton Menggunakan Certainty O Response Index (CRI).

Nadila, A. (2020). Miskonsepsi Peserta Didik Menggunakan Certainty O Response Index (Cri) Pada Materi Hukum Newton Tentang Gerak Di Sma Negeri 1 Darul Imarah.

Prasetya, L. A. (2018). Analisis Perubahan Konsep Tentang Usaha Dan Energi Melalui Bimbingan Belajar Individual Dengan Bantuan Multimedia Berbasis Kompuiter.

Rusilowati, A. K. (2016). Developing an Instrumen Of Scientific Literacy Asessment on The Cycle Theme. .

Sapitri Daniati, T. D. (2017). Miskonsepsi
Siswa Pada Materi Listrik Statis Di Kelas XII Sma Negeri 9 Pontianak .

Satya Sadhu, M. T. (2016). Analysis Of AcidBase Misconceptions Using Modified Certainty Of Response Index (CRI) And Diagnostic Interview For Different Student Levels Cognitive.

Triwulan, F. R. (2015). Implementasi Metode Certainly Of Response Index (CRI) Untuk Meningkatkan Aktivitas Hasil Belajar Pada Mata Pelajaran Sistem Komputer Kels X Ti A Di Smk Sakti Gelombang.

Zayyinah, F. M. (2018). Identifikasi Miskonsepsi Siswa Pada Siswa Smp Dengan Certainty Of Response Index (CRI) Pada Konsep Suhu Dan Kalor (Science Educational Conference). 